\title{
Lakota Female Scholarship: A Collective Case Study on Transcending Indigenous Educational Pathways and Persistence at the Graduate Level
}

\author{
Aspen Lakota Rendon (Corresponding author) \\ Argosy University \\ 1331 Raleigh Street, Denver, Colorado 80204, United States \\ Tel: 1-720-299-0927 E-mail: aspenrendon@hotmail.com
}

\author{
Ahmed Al-Asfour \\ Oglala Lakota College \\ 490 Piya Wiconi Road, Kyle, South Dakota 57752, United States \\ Tel: 1-605-430-5031Ｅ-mail: aalasfour@olc.edu
}

Received: June 23, 2019 Accepted: September 21, 2019

Published: September 24, 2019

doi:10.5296/jei.v5i2.14966 URL: https://doi.org/10.5296/jei.v5i2.14966

\begin{abstract}
This study explored the perspectives of seven Lakota females who graduated from Oglala Lakota College (OLC) master's degree in Lakota Leadership and Management or Lakota Leadership and Management with an emphasis in Education Administration programs. Education histories, cultural identification, and college experiences were evaluated to investigate what incentives, not only influenced but propelled the women through the world of academia. The research was qualitative in nature, thus giving a thorough examination of each student perspective. The qualitative research was conducted through a collective case study. Four themes identified through in the findings were: financial support, high female influence, cultural identification, and formal versus informal supports.
\end{abstract}

Keywords: Native American higher education, Lakota females, persistence, TribalCrit, Tribal colleges \& universities 


\section{Introduction}

The state of Indian education continues to be problematic in the 21 st century due to the historical impact of Indian education initiatives by the U.S. government. The disproportionate rates of American Indians (AI) obtaining graduate degrees compared to other racial groups is a result of these initiatives (Shotton, 2016; Tierney, Salle, \& Venegas, 2007). Native students, historically and continuously, hold the lowest graduation rates among all minority categories (Gibson, 2015). Tribal colleges and universities (TCUs), according to Thornton (2006) and Makomenaw (2014), are increasing their success with retention strategies, increased graduation rates, and improvement in transfer success rates among their student body. This study focused on the graduate experiences of Lakota females at Oglala Lakota College. Oglala Lakota College is an accredited higher education college, located on the Pine Ridge Indian Reservation, in the Southwest corner of South Dakota.

Indeed, numerous scholars have identified characteristics that propel students toward post-secondary education, but little is known about Lakota females who continue that momentum through graduate degree attainment on or near Indian reservations (Butler \& Al-Asfour, 2018; Shotton, Lowe, \& Waterman, 2013; HeavyRunner \& DeCelles, 2002; Guillory, 2008). Al-Asfour and Abraham (2016) encouraged Native American scholars and allies to work towards filling the gap of research related to retention and persistence for Native American students in higher education. Through our review of the literature, it is apparent that previous research, published on Native American students in higher education, have not focused on gender in the Northern Plains. The researchers felt this research was important due to the paucity of information currently available on Lakota female scholarship. This study contributes to the significant gap in the research with regard to Indigenous females, as it applies to graduate degrees and geographic location. The information found can also aid in assisting with the enrollment and retention rates for future graduate students in the service area.

\subsection{Tribal Colleges and Universities}

Tribal colleges and universities (TCUs) are influential in tribal communities due to their mission, location, and governance. Crazy Bull (2014) describes TCUs as unique, culturally rich and relevant, reservation-based, underfunded miracles, and the best-kept secret in education. Crazy Bull, Lindquist, and Gipp (2015) discuss the implications of the establishments of the TCUs, along with the Indian Self- Determination Act and Educational Assistance Act of 1978. They proclaim that these were pivotal in the development of proactive support for sovereign tribal nations.

In addition, The Tribally Controlled Community College Assistance Act of 1978 (TCCCAA) was later amended to the Higher Education Act, recognizing that tribes have an integral right to educate their citizens. Treaties uphold the right to education with the support of the federal government, as long as the foundation of the institutional was tribally governed. This groundwork was paramount to the Native leaders of the tribal college movement. Crazy Bull et al. (2015) narrated tribal control as the key membership criterion for inclusion in the American Indian Higher Education Consortium (AIHEC) and the TCCCAA. Pease-Pretty On 


\section{Macrothink}

Top (2003) recounts the organization of the first six tribal colleges that consorted in 1972-Sinte Gleska College (Rosebud, SD), Oglala Sioux Community College (Pine Ridge, SD), Turtle Mountain Community College (Belcourt, ND), Standing Rock Community College (Fort Yates, ND), Navajo Community College (Tsaile, AZ), and Hehaka Sapa College of D-Q University (Davis, CA).

\subsection{Oglala Lakota College}

Oglala Lakota College's initial goal was to become a community college when it was established in 1971. However, the College now offers vocational degrees, associates, bachelors, and master's degrees (Al-Asfour \& Bryant, 2011). OLC is one of three. TCUs that offer graduate degrees. The student population attending OLC, during the research period, was between 1400 and 1500 students. The College has one main college campus (Piya Wiconi) located near Kyle, South Dakota. There are also 11 district satellite sites where classes occur. Table 1 shows the number of graduates from all sites who graduated each year. The female graduate degree completion at OLC accounts for $85 \%$ of the total master's graduate-level achievement population while the male graduate degree population accounts for only $15 \%$ of the total graduate-level degree completion.

Table 1. Number of students who graduated from the Graduate Studies Program from Oglala Lakota College from 2010 through 2019

\begin{tabular}{|l|l|l|l|}
\hline Graduate Pool & N & M & F \\
\hline Academic Year & 9 & 0 & 9 \\
\hline 2010 & 3 & 0 & 3 \\
\hline 2011 & 12 & 5 & 7 \\
\hline 2012 & 7 & 0 & 7 \\
\hline 2013 & 3 & 0 & 3 \\
\hline 2014 & 5 & 0 & 5 \\
\hline 2015 & 7 & 0 & 7 \\
\hline 2016 & 5 & 0 & 4 \\
\hline 2017 & 8 & 3 & 11 \\
\hline 2018 & 5 & 3 & 8 \\
\hline 2019 & 75 & 11 & 64 \\
\hline Total & 5 & 0 & \\
\hline
\end{tabular}

\section{Native American Women in Higher Education}

This term education takes on several different meanings, depending on the context utilized and time frame it is referred to within. Trujillo and Alston (2005) suggested that, culturally, it 
is the practice that American Indian/Alaskan Native communities utilize to pass on their knowledge from one generation to the next. This could be extended to include, not just the practice or process, but the manner in which the knowledge, experiences, and values are consistently taught. The educational research and policy implications of this term are also important because they reflect the academic performance and outcomes of students who attend tribal colleges. For the college classroom practitioners, Indian education refers to the instructional approaches and pedagogy that are culturally relevant and utilized to guide toward accomplishing the outcomes set forth by the governmental agencies that grant accreditation for the colleges.

The journey of educational attainment for American Indian females is one of many varying paths and detours. The role of the American Indian female in the world of academia is now changing. The benefits of investing in academics for this population affect the individual, family, and community as a whole. The Institute for Higher Education (2007) stated, "For many Native women those journeys represent the best and most important opportunities available for cultural preservation and growth, social mobility, and economic prosperity" ( $p$. 5). The women of the Lakota Nation are now accepting this as truth and pursuing paths of education that were previously, seemingly unreachable to many of their family members.

There have been few studies that focused on Native American college students. In 2008, Brandt conducted a qualitative study with four Navajo female students in science, citing that culture and family were essential into their success in higher education. Other similar studies such as White Shield (2009) reported that family was central in the lives of women together with culture strength, which provides a resiliency factor in their academic experience. In a study by Shotton (2008), eight Native American women, who received doctoral degrees, described challenges with overt and covert racism. These participants credited family, community, and supportive faculty for their graduate degree success.

Despite the availability of some literature on Native American students in higher education, there is a paucity of research related specifically to the Lakota people. Al-Asfour and Bryant (2011) described the challenges Lakota students encounter, which were flexibility, transportation, communication, and technical support. Gambrell (2016) conducted a study related to Lakota women leaders where Gambrell found that "get educated" was a major theme for Lakota female leaders. The participants in Gambrell (2016) study highlighted the need for Lakota female leaders to pursue advanced degrees to better serve the community. However, there has not been any study available in the literature related to Lakota female students in higher education. This study provides the promise of increasing awareness and understanding of the impact TCUs are making for American Indian students and communities by documenting strategies that result in educational success. It provides alternative perspectives on the educational richness that has not been visible outside TCUs across the United States.

\section{Theoretical Framework}

Tribal Critical Race Theory (TribalCrit) served as the framework for this study. In 2006, Brayboy developed Tribal Critical Race Theory, which has roots in Critical Race Theory 
(CRT). According to Brayboy (2006), TribalCrit allows researchers to develop a lens to construct and "address the complicated political relationship between American Indians and the United States federal government" (p. 427). One of the components of TribalCrit is to recognize that government and educational policies towards American Indians have "historically, been oriented toward a problematic goal of assimilation" (p. 436). Although CRT discusses racism in society and the educational system, Brayboy (2006) argued that it lacks recognition of the issues of American Indian sovereignty and the colonization of tribes. TribalCrit provided us with the lens and served as the framework for this study.

Brayboy (2006) proposed the following tenets of TribalCrit that address the unique experiences and status of American Indian people. TribalCrit tenets connect directly to the classrooms that American Indian students attend each day. These classrooms usually take on a multicultural education cover, which typically focuses on a combining or melting pot of cultures, clustering Native Americans into the large colonial group who dry meat, make their clothing, sing around a campfire, and dance. Writer (2008) supports the use of TribalCrit to inform the larger society and subtract the surface level propaganda of "food, fun, festivals, and foolishness" from the multicultural education system. Although some of the songs and dance aspects are a large part of the culture, they are not one of the four themes that were found to be the reasons why Lakota females thrive in the world of academia and their communities. When the larger society starts to recognize that Indigenous women have deep substance and a wealth of knowledge to share, there will be a beginning to understanding how vital our Indigenous Nations are to the world.

The concepts of knowledge, culture, and power take on new meaning when examined through an Indigenous female lens. Government and educational policies toward Indigenous people are intimately linked around assimilation, tribal philosophies, beliefs, traditions, and visions for the future (Brayboy, 2006). These are all central to understanding the lived realities of the Lakota females in this study. These realities are told through personal experiences shared by the participants. These various narratives of differences and adaptability are legitimate sources of data. They are what solidifies the theoretical framework of these Indigenous educational histories not being rooted in the white supremacy and the desire for the material gain of U.S. Policy. Instead, they truly occupy a space of tribal sovereignty, tribal autonomy, self-determination, and self-identification through educational success and community leadership (Brayboy, 2006).

\section{Methodology}

A collective case study design (Stake, 2000) was utilized to examine the factors related to successful graduate degree attainment. Mirriam (2009) stated that a case study is an "in-depth description and analysis of a bounded system" (p. 40). The bounded system is the "what" that is being studied. The bounded system of this research study is capturing the experiences of Lakota female graduates of all graduate programs at OLC between the years of 2010-2016. Yin (2014) described a case study as responding to the "how" or "why" of a social phenomenon; is replicable, and occurs within a framework of real-life contexts. This research aimed to answer the "how" and "why" these Lakota females were able to be successful 
through the graduate level. It aimed at discovering how these women were able to work through the inequalities and disproportions of the reservation and surrounding communities. The study was also replicable due to all participants answering the same interview questions and completing the same Northern Plains Bicultural Inventory-Revised (NPBI-R) for document review. NPBI-R is designed to measure four levels of cultural affiliation: traditional, assimilated, bicultural, and marginalized. It was important and relevant to the study due to the need to have a measure of cultural affiliation. If one of the criteria for participants was to be self-identified as Oglala Lakota, then there had to be a way to measure the cultural affiliation.

Creswell (2013) defines qualitative research as the use of theoretical frameworks to inform research about individuals or groups attributed to any social or human phenomenon or problem. Qualitative research was appropriate for this study due to the researchers looking at OLC's female graduate programs through the experiences of the participant's personal stories and perspectives. The method by which researchers collected data is justified by the variables of academic completion at the graduate level for Lakota females at a TCU. This is a complex issue that requires detailed information, which can only be established by talking to people and allowing them to tell their stories, from their own perspectives, without assumptions of cause or reasoning.

The notion of oral stories and personal perspectives being solid data allowed the Lakota females to add to the literature about Indigenous educational success and journeys. TribalCrit shaped the research by enabling us to see how colonization affected the Native educational community and provided a lens on the insight that Native females have in these systems that were put in place on the reservations, as well as their navigation through such systems (Brayboy, 2006).

\subsection{Research Question}

The research question guiding this study was: What experiences propelled Lakota Females at Oglala Lakota College to completion of a graduate program?

\subsection{Selection of Subjects}

There were a total of seven participants chosen to participate in this research study. The relatively small samples size was selected for an in-depth inquiry. Purposeful random sampling was utilized. Patton (1990) signified purposeful sampling as the one major distinction between quantitative and qualitative research. Devers and Frankel (2000) described this type of sampling as a method of diving deeper into the understanding of selected individual participant's or a group's experiences. Purposeful sampling allows researchers to approach and choose participants based on specific criteria. The three criteria for the study included: the participant must be a graduate of any graduate program at OLC between 2010 and 2016, self-identified as being Oglala Lakota, and female. There was no requirement that the participants' undergraduate degree obtained was from a tribal college. Since the population sample size was limited and had such specific boundaries, the results were not generalized to the broader population. 


\subsection{Data Collection}

Three sources of data were utilized for the study to access what Gill, Stewart, Treasure, and Chadwick (2008) consider a more profound understanding of a social phenomenon, personal interviews were conducted as the first method to collect data. The second source was the collection of responses to The Northern Plains Bicultural Inventory-Revised (NPBI-R). According to Kagan and Gray (2011), the NPBI-R was designed to measure four levels of cultural affiliation: traditional, assimilated, bicultural, and marginalized. This instrument was revised to match the purpose of the study structure. This document was important to the qualitative research as it was utilized to assess cultural affiliation and triangulate themes in the data. Since the educational model that all western society schools used was different than the Lakota culture of origin, it was necessary to measure cultural orientation.

The third source of data was researcher observation. These observations were housed in a journal and documented the researchers' experiences as they pertained to distance traveled, road conditions, home conditions, atmosphere, participant body language, and any themes or ideas that presented themselves at the time. Mulhall (2003) discussed the unstructured observation approach in qualitative research as it allows observing participants' psychical reaction to certain words or response to particular discussion topics. Unstructured observations were appropriate and utilized in this research to describe and interpret the naturalistic patterns of the participants.

\subsection{Data Processing and Analysis}

Data analysis took place on a continual basis and from an ethnographic lens. Miles and Huberman (1994) explained how an ethnographic data analysis reaches across multiple data sources and focuses on the descriptive information provided by the participants. The data was collected, coded for themes and relationships, then confirmed and validated. Although they were all separate tasks, each one aided in building a solid picture of participant experiences and educational histories.

The interviews were transcribed verbatim by the researchers. These transcriptions were then grouped by day, time, and participant. Lastly, the transcripts were hand-coded by the researchers. The researchers did not utilize a computer program to code for themes. This was a deliberate strategy in order to fully recognize and intimately work with the information gathered from all participants. These themes and patterns were assessed both individually and as a group.

Identifying relationships among categories was done by using colored highlighters to highlight specific sections of the transcribed interviews. The researchers used pink for the female influence, green for financial aspects, yellow for formal factors, and orange for informal factors. Each piece of information was then placed on a colored sticky note and put on a wall to be moved around to show how the relationships between codes and categories. An interim analysis was on-going and non-cyclical. It was a continuous process recorded throughout the research study and was documented in the researchers' observation journal.

Furthermore, the researchers' made use of member checking and triangulation in order to 
ensure validity. The member checking was vital to integrate a process where the participants validated the information being shared was reflective, and an accurate account of their thoughts and actions throughout their graduate degree attainment journey. Creswell (2007) stated that the triangulation process aides in shedding light on themes and perspectives from different sources. The sources triangulated to bring forth an accurate account of themes among the data sources: researchers' journal, Northern Plains Bi-cultural Inventory-Revised, and the interviews.

\subsection{Researchers' Positionality}

The primary author is an Oglala Lakota female who has experience in $\mathrm{K}-12$, collegiate, and alternative adult education. Her passion to research female scholarship and educational pathways stems from a need to give back to her community and showcase Indigenous people for their many strengths. She purposefully chose to attend tribal college for a portion of her undergraduate and one of her graduate degrees. Her work in her community includes working at the district level in educating teachers and administrators on Indigenous presence and topics within classrooms, equity work within the district, and community involvement with educational youth programs. She is also a founding member of the Colorado chapter of Women Empowering Women of Indigenous Nations. The second author is an Arab-American Professor and Department Chair at a Tribal College. He has spent more than 10 years serving Native American communities, attended many ceremonies such as Sundance, consulted for tribal organizations and published articles both peer-reviewed and non-peer reviewed in higher education and career development related to Native Americans.

\section{6 Limitations}

Despite the contributions of this study to fill a void in the literature and further the discourse of Lakota female students in higher education, there are some limitations that should be noted when interpreting its findings. Although the study explores the perspective of seven Lakota graduate female studying at Oglala Lakota College, the results should not be generalized to other Native American females. Native Americans have different cultures, traditions, spirituality, and languages. Findings from one study with seven female students should be drawn on to provide insight without concluding specific results to a culture or subcultures. Also, this study was conducted at one TCU. The findings might not apply to other TCUs or other higher education institutions in varying geographic regions. It would be interesting to see similar studies being replicated at other TCUs or minority-serving institutions with a larger female sample. We encourage other researchers in the field of student affairs studying or researching minorities in higher education to use this study as a lens to explore Native American females in higher education.

\section{Results}

While performing the coding processes and triangulation of data, four themes were identified: (1) high female influence, (2) formal vs. informal support, (3) financial support, and (4) cultural identification. Figure 1 illustrates the four major themes that surfaced. Each theme is discussed in detail with regard to how each participant contributed to the patterns within each 


\section{Macrothink

theme. We chose to display each participant individually to provide readers a perspective for each of the participants.

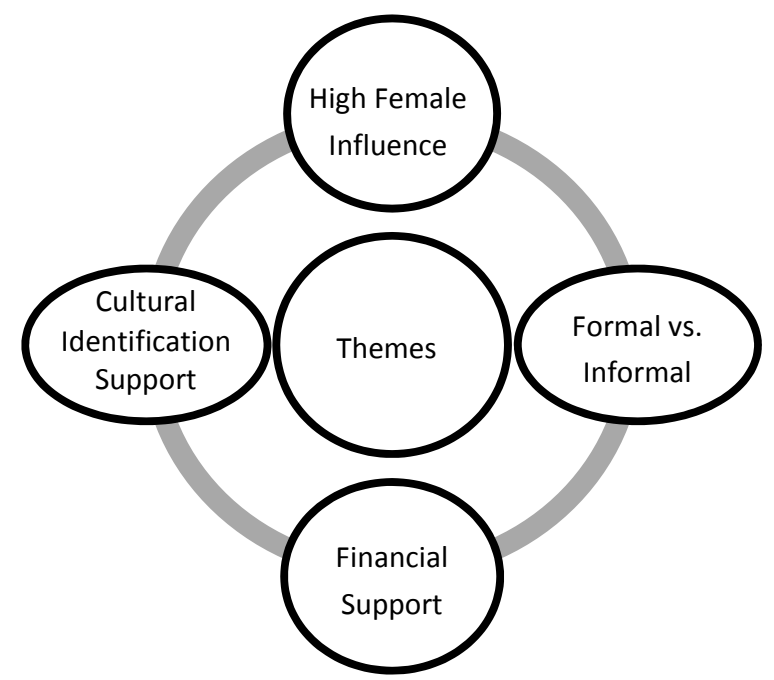

Figure 1. Themes. This figure represents the four major themes that were identified from the data analysis and triangulation of information

High female influence: All participants shared perspectives of a female influencer in their educational journey to graduate degree attainment. Reinforcement from female influencers, and the family was essential as a factor of persistence for these Lakota females. The women weaved together stories of strength, struggle, and support that came from their mothers, grandmothers, aunts, sisters, cousins, and peers.

Formal vs. informal processes: As the participants discussed the various processes they had to navigate, it became apparent that formal and informal routes of navigation were defined. Formal processes are the aspects of the program in which the college can assess and address. The informal processes are the aspects of the graduate program that are not taught as part of the curriculum map from the school. These informal processes are often immeasurable but vital to the success of the participants.

Financial support: Although all participants obtained degrees from the same graduate program, many achieved this success through various financial avenues. Some participants received grants, others paid through their employer programs, and one paid for the program on her own with assistance through scholarships. Financial support can provide an important point of access to higher education for Native American students (Reyes \& Shotton, 2018). Nelson and Tachine (2018) affirmed that both institutions of higher education and Native nations help students meet the financial aid needs of Indigenous students.

Cultural identification: The participants who identify more with being traditional had a high identification with American Indian culture and low identification with European American 
culture. Participants who were classified as assimilated tended to be lower in American Indian identification and higher in identifying with European American culture. Bicultural participants were said to have high identification with both cultures. The marginalized participants were low in both American Indian and European American cultures. One group was not better than the other, and all participants had graduated from graduate school. Even though all of the participants were Lakota females, there was a variance in how culturally involved each participant was with their Native culture and with the Western European culture.

All participants completed the Northern Plains Bicultural Inventory-Revised. It asked a series of questions on a Likert scale of 1-5. There were four possible outcomes: traditional, assimilated, bicultural, and marginalized. Figure 2 illustrates where participants fit according to their answers on how they identify when completing the NPBI-R.

\begin{tabular}{|l|l|l|}
\hline \multirow{2}{*}{ European American Culture } & \multicolumn{2}{|c|}{ American Indian Culture } \\
\cline { 2 - 3 } & High & Low \\
\hline \multirow{4}{*}{ Low } & Bicultural & Assimilated \\
& $\bullet$ Rochelle & \\
& $\bullet$ Matraca & \\
\hline \multirow{3}{*}{ High } & Takota & \\
& Traditional & Marginalized \\
& $\bullet$ Doreen & $\bullet$ No participants \\
\hline
\end{tabular}

Figure 2. How the participants culturally identify according to their answers on the NPBI-R

\section{Participants}

Each participant will be briefly introduced by their education and the outcome of the four major themes. Pseudo names have been chosen by the participant to protect their identity. There is also limited personal information or description about each participant due to the native community being very small and a potentially high risk of information shared having a negative and harmful effect for the participants.

\subsection{Wicahpi}

Wicahpi is a petite woman. As we approached her front door, she was talking to her horses and apologizing for not visiting them for a couple of days. Her home had a very country feel. She had feminine energy about her and, there was a sense of strength in her home and her presence. She lived alone, drove a truck, kept an orderly house, and cared for many animals. She was born off the reservation but was mobile between the city and reservation throughout 
her whole life. She has been a business owner and an educator for many years.

\begin{tabular}{|c|c|c|c|c|}
\hline High $F$ & Formal Processes & Informal Processes & Financial Support & Cultural Iden \\
\hline $\begin{array}{l}>\quad \text { Raised by mother } \\
\text { and grandmother. } \\
\text { American Indian } \\
\text { Relocation Program, } \\
\text { Importance of education } \\
\text { was passed down for four } \\
\text { generations. } \\
>\quad \text { Most of her older } \\
\text { family members are } \\
\text { college educated or at } \\
\text { least attended college. }\end{array}$ & $\begin{array}{l}\text { Did not start in a } \\
\text { cohort. } \\
\text { independently. } \\
>\quad \text { Frustration due } \\
\text { to classes needed not } \\
\text { being offered due to } \\
\text { low student } \\
\text { enrollment. } \\
>\quad \text { Grant program } \\
\text { started and she joined a } \\
\text { cohort. } \\
\text { Class } \\
\text { availability increased. } \\
>\quad \text { Frustration due } \\
\text { to changing of rules, } \\
\text { practices, and } \\
\text { deadlines throughout } \\
\text { the program with little } \\
\text { notification. } \\
>\quad \text { This one fact } \\
\text { almost led to her not } \\
\text { graduating. }\end{array}$ & $\begin{array}{l}>\quad \text { Transportation and } \\
\text { money not an issue. } \\
>\quad \text { Held a good job. } \\
>\quad \text { Had reliable } \\
\text { transportation. } \\
>\quad \text { Barriers. } \\
>\quad \text { College faculty at } \\
\text { odds. } \\
>\quad \text { Instructors had to } \\
\text { persevere through } \\
\text { program. } \\
>\quad \text { Lack of Lakota } \\
\text { specific research. }\end{array}$ & $\begin{array}{l}>\quad \text { Employer Paid } \\
\text { programming. } \\
>\quad \text { Money ran out. } \\
>\quad \text { Employer program } \\
\text { ended. } \\
>\quad \text { Grant cohort } \\
\text { started. } \\
>\quad \text { Joined cohort } \\
\text { grant program. } \\
>\quad \text { Received a laptop. } \\
>\quad \text { Internet services } \\
\text { paid. }\end{array}$ & $\begin{array}{l}>\text { Traditional. } \\
\text { pseudo name. } \\
\text { Indian culture. } \\
\text { Nigh in American } \\
\text { not fluent. } \\
>\quad \text { Uses common } \\
\text { Lakota sayings on a daily } \\
\text { basis. } \\
>\quad \text { Grandfather is } \\
\text { fluent in Lakota. } \\
>\quad \text { Growing up, she } \\
\text { didn't realize she was } \\
\text { Indian and was scared of } \\
\text { Indians. } \\
>\quad \text { Low in European } \\
\text { American culture. } \\
>\quad \text { Primarily English } \\
\text { spoken in the home. }\end{array}$ \\
\hline
\end{tabular}

\subsection{Allison}

When we met with Allison, she was smiling but had a look as if she was not sure about meeting with us. We felt a high level of anxiety from her in her questioning of how the interview was going to be run and what she was willing to do and not willing to do. She seemed more at ease knowing that she would not be named and we would not provide revealing details about her personally. Once we started talking, Allison loosened up and shared some very heartfelt and emotional experiences in her graduate program journey. 


\begin{tabular}{|c|c|c|c|c|}
\hline High Female Influence & Formal Processes & Informal Processes & Financial Support & Cultural Identification \\
\hline $\begin{array}{l}\text { Two parent } \\
\text { household. } \\
\text { sisters. } \\
>\quad \text { Nine brothers \& } \\
\text { school through } 11^{\text {th }} \\
\text { grade. } \\
\text { Job Corps. } \\
>\quad \text { Mother was a } \\
\text { homemaker. } \\
>\quad \text { Father earned a } \\
\text { bachelor's degree. } \\
>\quad \text { Six out of the nine } \\
\text { siblings have earned } \\
\text { various degrees. }\end{array}$ & $\begin{array}{l}>\text { The most } \\
\text { trying process of } \\
\text { program. } \\
>\quad \text { Program was } \\
\text { in transition. } \\
>\quad 3 \text { temporary } \\
\text { directors. } \\
>\quad \text { Position } \\
\text { vacant for some time. } \\
>\quad \text { Secretary \& } 1 \\
\text { full time teacher } \\
\text { running the program. } \\
>\quad \text { Instructors not } \\
\text { prepared to run the } \\
\text { program and teach. } \\
>\quad \text { Lack of } \\
\text { formal mentorship. }\end{array}$ & $\begin{array}{l}>\quad \text { Classes all close } \\
\text { to her home. } \\
\text { issue. } \\
>\quad \text { Travel not an } \\
\text { formed based on } \\
\text { personal relationships. } \\
\text { Post-Traumatic } \\
\text { Stress Disorder (PTSD) } \\
\text { from navigation of } \\
\text { processes on her own, } \\
\text { by trial and error. } \\
>\quad \text { High expectation } \\
\text { of helping others while } \\
\text { she was unsure of } \\
\text { success herself. } \\
>\quad \text { High stress on a } \\
\text { regular basis resulted in } \\
\text { hair loss. }\end{array}$ & $\begin{array}{l}>\text { Government } \\
\text { grant. } \\
\text { fees paid for. } \\
\text { Internet and gas } \\
\text { stipend. } \\
>\quad \text { The possibility } \\
\text { of having to pay all of } \\
\text { this money back if she } \\
\text { didn't finish aided her } \\
\text { in deciding to finish. }\end{array}$ & 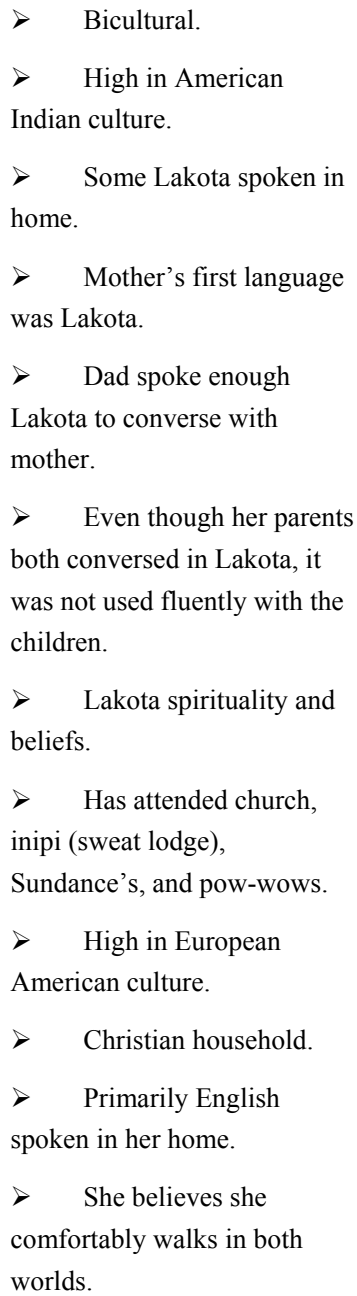 \\
\hline
\end{tabular}

\subsection{Dakota}

When Dakota entered the room, she was very focused. We had an early morning interview, and she was dressed very colorfully with sparkly jewelry accents. Her interview sheet was pre-filled, and she commented about not wanting to forget her thoughts. Her thoroughness matched her intentional demeanor, which had afforded her successful completion of three degrees. Dakota has lived on and off the reservation, but still considers the reservation her home. 


\begin{tabular}{|c|c|c|c|c|}
\hline High Female Influence & Formal Processes & Informal Processes & Financial Support & Cultural Identification \\
\hline $\begin{array}{l}>\quad \text { Raised by her mom. } \\
>\quad \text { Single parent household. } \\
>\quad \text { Mom earned } \\
\text { undergraduate degree and three } \\
\text { masters' degree's. } \\
>\quad \text { Education always } \\
\text { stressed in home. } \\
>\quad \text { Her dad was raised by his } \\
\text { mom and grandmother } \\
>\quad \text { Dad earned an } \\
\text { accounting degree. }\end{array}$ & $\begin{array}{l}\text { No processes were } \\
\text { abnormally difficult. } \\
\text { education off the } \\
\text { reservation so she was } \\
\text { aware of navigating } \\
\text { higher education system. } \\
\quad \text { Classes were } \\
\text { intentional with their } \\
\text { school to community } \\
\text { connections. } \\
\quad \text { Spoke highly of } \\
\text { one instructor she had for } \\
\text { several classes. } \\
\quad \quad \text { Information was } \\
\text { presented in linear and } \\
\text { chronological order (This } \\
\text { was more to her learning } \\
\text { style than the circular } \\
\text { way some Lakota classes } \\
\text { are taught). }\end{array}$ & $\begin{array}{l}\text { Worked } \\
\text { autonomously since } \\
\text { not part of a cohort } \\
\text { program. } \\
\text { mentoring or tutoring. } \\
\quad \text { Self-guided } \\
\text { student. } \\
\text { "It was up to you how } \\
\text { much you wanted to } \\
\text { learn and how much } \\
\text { you put into it" } \\
\text { (Personal } \\
\text { communication, } \\
\text { February } 4,2017 \text { ). }\end{array}$ & $\begin{array}{l}\text { Tuition paid } \\
\text { for through an } \\
\text { endowment } \\
\text { program. } \\
\text { No stipends, } \\
\text { grants, or } \\
\text { scholarships. }\end{array}$ & $\begin{array}{l}>\quad \text { Bicultural. } \\
>\quad \text { High American } \\
\text { Indian culture. } \\
>\quad \text { Utilizes familiar } \\
\text { phrases. } \\
>\quad \text { Taking Lakota } \\
\text { language classes with } \\
\text { her son. } \\
>\quad \text { High European } \\
\text { American culture. } \\
>\quad \text { English speaking } \\
\text { household. }\end{array}$ \\
\hline
\end{tabular}

\subsection{Molli}

Molli had a very relaxed and welcoming demeanor as I entered her home. We sat at a large dining room table, where she was very curious about how I would be reporting my findings. After assuring her that her identity would be confidential and protected, she took out her questionnaire sheet to refer to during the interview. Molli has been in education for over 20 years and holds three degrees. She has lived on and off the reservation, for various amounts of time, for most of her life.

\begin{tabular}{|c|c|c|c|c|}
\hline High Female Influence & Formal Processes & Informal Processes & Financial Support & Cultural Identification \\
\hline $\begin{array}{l}\text { Raised primarily by her } \\
\text { mother and grandmothers. } \\
\text { school. } \\
>\quad \text { Mother did not finish } \\
\text { realize she wanted to be an } \\
\text { educator. }\end{array}$ & $\begin{array}{l}>\quad \text { Had attended } \\
\text { graduate school at a } \\
\text { non-tribal college or } \\
\text { university. } \\
>\quad \text { Two faculty } \\
\text { provided mentorship } \\
\text { through essential } \\
\text { processes. } \\
>\quad \text { One instructor was } \\
\text { essential to her career } \\
\text { development and } \\
\text { attributed to her success. } \\
>\quad \text { This one instructor } \\
\text { increased her Lakota } \\
\text { cultural competency. }\end{array}$ & $\begin{array}{l}>\quad \text { Location of } \\
\text { classes was } \\
\text { convenient. } \\
>\quad \text { Personal and } \\
\text { family issues were } \\
\text { the biggest obstacle. }\end{array}$ & $\begin{array}{l}>\quad \text { Grant program. } \\
>\quad \text { This program } \\
\text { included time limit } \\
\text { requirements in } \\
\text { obtaining certifications } \\
\text { or else had to pay back } \\
\text { all money. } \\
>\quad \text { Tuition \& books } \\
\text { paid for. } \\
>\quad \text { Gas Vouchers. } \\
>\quad \text { Some meals } \\
\text { were provided. }\end{array}$ & $\begin{array}{l}>\quad \text { Assimilated. } \\
\text { Indian culture. } \\
>\quad \text { High in the } \\
\text { European American } \\
\text { culture. } \\
>\quad \text { Only English } \\
\text { spoken in her home. } \\
>\quad \text { Grew up hearing } \\
\text { Lakota, Spanish, and } \\
\text { English. }\end{array}$ \\
\hline
\end{tabular}




\subsection{Matraca}

Upon entering Matraca's home, it was busy and full of life. She was in the kitchen with one of her children cleaning. She had a very open and bubbly personality. She notified her children that she would be in her room doing an interview and gave instructions not to bother her. She had full confidence that her children would not interrupt. Matraca has been in education for over 20 years. She has been mobile with living on and off of the reservation her whole life. She holds two degrees.

\begin{tabular}{|c|c|c|c|c|}
\hline High Female Influence & Formal Processes & Informal Processes & Financial Support & Cultural Identification \\
\hline $\begin{array}{l}\text { Mom was always } \\
\text { in school. } \\
\text { educational role models } \\
\text { in her community. } \\
>\quad \text { Sister had } \\
\text { Master's degree. } \\
>\quad \text { Uncle had } \\
\text { Master's degree. } \\
>\quad \text { Brother had } \\
\text { professional license. }\end{array}$ & $\begin{array}{l}\text { Cohort. } \\
\text { leadership } \\
\text { foundation of the } \\
\text { program. Professors } \\
\text { were Lakota and } \\
\text { brought in Lakota } \\
\text { thought and } \\
\text { practices. } \\
\quad \text { Method of } \\
\text { teaching classes were } \\
\text { supportive and } \\
\text { positive. } \\
\\
\text { "I was really enticed } \\
\text { because I was able to } \\
\text { take classes that were } \\
\text { surrounded in the } \\
\text { foundations of } \\
\text { Lakota thought and } \\
\text { philosophy." }\end{array}$ & $\begin{array}{l}>\quad \text { Faculty } \\
\text { member held } \\
\text { informal group study } \\
\text { on Sundays. } \\
>\quad \text { Mother of } \\
\text { multiple children. } \\
>\quad \text { Full time job. } \\
>\quad \text { Had support } \\
\text { in her home with } \\
\text { kids, cooking, and } \\
\text { cleaning. }\end{array}$ & $\begin{array}{l}\text { Grant Program. } \\
\text { paid for. } \\
\text { for Internet and gas. } \\
\text { service payback for the } \\
\text { grant program. } \\
\text { "Fortunate enough } \\
\text { that right after } \\
\text { receiving my degree I } \\
\text { was able to find an } \\
\text { administrative job and } \\
\text { my service payback } \\
\text { was done right away." } \\
\text { (Personal } \\
\text { communication, } \\
\text { February 7, 2017) }\end{array}$ & $\begin{array}{l}>\text { Bicultural. } \\
\text { culture. } \\
>\quad \text { Bigh American Indian } \\
\text { home (numbers, colors, good } \\
\text { morning, go to bed, sit down, } \\
\text { behave, and parts of our prayers). } \\
>\quad \text { Mothers' beliefs were } \\
\text { described as Lakota spirituality. } \\
>\quad \text { Participates in the } 7 \text { sacred } \\
\text { Lakota ceremonies. } \\
>\quad \text { Pow-wow dancer. } \\
>\quad \text { High European American } \\
\text { culture. } \\
>\quad \text { European father. } \\
>\quad \text { No set religion on father's } \\
\text { side. } \\
>\quad \text { Mainly English spoken at } \\
\text { home. }\end{array}$ \\
\hline
\end{tabular}

\subsection{Rochelle}

Rochelle greeted me with a hug and quiet excitement. She introduced me to her family before they left the room, and we began our interview. Throughout the interview, Rochelle was comfortable enough to share feelings that made her emotional and even shed a few tears. Her life and the graduate journey had been full of emotion, happiness, and responsibility. There have been many people who have guided her and provided direction in tough times. She seemed to be very compassionate and thoughtful.

Rochelle has worked in the education field for over 15 years. She was born off of the reservation but moved there when she was about one-year-old. She resided on the reservation until it was time to move away for college. She then returned to reservations where she has spent most of her adult life after college. Rochelle has two degrees and one endorsement certificate. 


\begin{tabular}{|c|c|c|c|c|}
\hline High Female Influence & Formal Processes & Informal Processes & Financial Support & Cultural Identification \\
\hline $\begin{array}{l}>\quad \text { Long line of } \\
\text { educated females. } \\
\text { a registered nurse. } \\
>\quad \text { Mother has } \\
\text { bachelors, master, and } \\
\text { two certificates. } \\
>\quad \text { There is a desire to } \\
\text { keep up with them. }\end{array}$ & $\begin{array}{l}>\quad \text { Cohort. } \\
>\quad \text { Selection of } \\
\text { Experienced \& } \\
\text { community members. } \\
>\quad \text { Instructors were } \\
\text { not knowledgeable in } \\
\text { navigating processes in } \\
\text { and out of college } \\
\text { system. } \\
>\quad \text { Overwhelming. } \\
>\quad \text { Help her children } \\
\text { navigate them now. }\end{array}$ & $\begin{array}{l}\text { Higher } \\
\text { capacity for } \\
\text { flexibility than non- } \\
\text { tribal colleges \& } \\
\text { universities. } \\
\text { One faculty } \\
\text { member highly } \\
\text { understanding and } \\
\text { supportive. }\end{array}$ & $\begin{array}{l}>\quad \text { Grant } \\
\text { Program. } \\
>\quad \text { Two income } \\
\text { home. }\end{array}$ & $\begin{array}{l}>\quad \text { Bicultural. } \\
\text { culture. } \\
>\quad \text { High in American Indian } \\
\text { home. } \\
>\quad \text { Practice traditional way } \\
\text { of spirituality. } \\
>\quad \text { High in European } \\
\text { American culture. } \\
>\quad \text { English is main language } \\
\text { spoken in home. } \\
>\quad \text { Catholic. }\end{array}$ \\
\hline
\end{tabular}

\subsection{Doreen}

Doreen presented herself as very into fitness and art. Her native jewelry stood out as accents against her skin. Her clothing was very colorful. She reminded me of those types of women who can work out for an hour and still look flawless. Doreen was very open and emotional in speaking about the people in her life who have motivated and supported her throughout her many paths. She was also very open about the struggles she encountered as a young girl, throughout her schooling, as a young adult, throughout her graduate school years, and current struggles. Doreen grew up, mainly, in urban settings off the reservation. Although, through her upbringing by her grandparents, her roots to the reservation are very strong. She holds five degrees.

\begin{tabular}{|c|c|c|c|c|}
\hline High Female Influence & Formal Processes & Informal Processes & Financial Support & Cultural Identification \\
\hline $\begin{array}{l}\text { Born to teen parents. } \\
\text { grandmother and } \\
\text { grandfather. } \\
\text { Gelieved strongly in } \\
\text { education. } \\
\text { most influence on her. } \\
\text { Doreen's grandmother told } \\
\text { her, "There's always going } \\
\text { to be time for family, there } \\
\text { will be time for kids, for } \\
\text { husbands, so put your } \\
\text { education first." }\end{array}$ & $\begin{array}{l}\text { Classes unavailable due } \\
\text { to low enrollment when } \\
\text { starting program. } \\
\text { available. } \\
>\quad \text { Joined cohort. } \\
>\quad \text { Low guidance. } \\
>\quad \text { No director. } \\
\text { One instructor to give } \\
\text { guidance and teach most } \\
\text { courses. } \\
\text { "I learned more from him in } \\
\text { one year of graduate studies } \\
\text { classes than I did from my } \\
\text { entire undergraduate degrees" } \\
\text { (Personal communication, } \\
\text { February } 12,2017 \text { ). }\end{array}$ & $\begin{array}{l}>\quad \text { Personal } \\
\text { issues outside of } \\
\text { program proved to be } \\
\text { a struggle. } \\
>\quad \text { One faculty } \\
\text { personally coached } \\
\text { her through finishing. }\end{array}$ & $\begin{array}{l}>\quad \text { Tuition fully } \\
\text { paid by scholarships } \\
\text { and awards. }\end{array}$ & $\begin{array}{l}>\quad \text { Traditional. } \\
\text { Indian culture. } \\
\text { phrases in Lakota. } \\
\text { Lakota on a daily basis. } \\
\text { Tries to speak } \\
\text { American culture. } \\
\text { L } \quad \text { Speaks mainly } \\
\text { English in home. }\end{array}$ \\
\hline
\end{tabular}




\section{Discussion}

In this study, seven Lakota females shared their personal narratives about what and/or who propelled them through the completion of a graduate program at Oglala Lakota College. The participants varying experiences were based on where they were raised, who they were raised by, differences in culture and religion during their upbringing, K-12 educational experiences, and post-secondary experiences. Researchers such as HeavyRunner and Decelles (2002), Huffman (2003), Schmidtke (2008), and many others have agreed that family members play a significant role in Native American students' success in higher education.

This study demonstrates the strong presence Lakota females have within their communities and family, whether immediate or extended. Even though they all have advanced degrees, they do not separate themselves from their tribal community regardless of whether or not they "physically" live on or away from their reservations or tribal communities. They see themselves as resources for their communities. The participants echoed this during the interviews, and other studies have confirmed the role of the family to Native American students' success (Al-Asfour \& Abraham, 2016; Shotton, Lowe, \& Waterman, 2013).

Lakota people are intricately tied to their communities in ways that transform and leave behind physical space or distance. They were also able to survive in school systems, communities, and workplaces that were absent of Lakota culture. On the other hand, it made them appreciate and value working, living, and/or attending school in communities that have and share Lakota culture with the adults and youth alike. Most of the participants talked about the generations, up to the 4th generation, above themselves investing in and valuing education. As a result, they are attempting to mentor and inspire the next generation to create a better life. Mentoring and working to enhance one's community is part of the student success model for Native American students developed by Pavel and Inglebret (2007). Also, the participants in this study all implied, explicitly and implicitly, that pursuing an advanced education was for the purpose of assisting, in some way, the tribal community. Essentially, every participant sought jobs or was currently in a position, that benefited Indian people or tribal communities in some way. This notion of improving oneself to give back to the community, once again, proves how vastly different the Lakota culture is from the colonization, imperialism, and desire for material gain which Brayboy (2006) speaks about in his TribalCrit theory.

The vital role which females play in the lives of their families and communities are consistently overlooked. This is why it is paramount that researchers no longer study the educational experiences of Lakota females from a deficit model or perspective. This is not to say that there are not personal struggles and aspects of college programming that do not fit the needs of students. It is to say there are Lakota females who are finding success and negotiating access to a brighter future for the generations to come due to their diligence and willingness to fight for what they believe to be possible and attainable.

Current programs that focus on what students lack instead of personal experiences and perspectives, aimed at what worked for them, will only increase the number of experts that can, yet again, provide information in helping to understand why Native American students 
fail at the various levels within the educational system. There should be increased coverage of academic discourse around why and how Indigenous students are achieving academic success. When these conversations continue to happen on a more frequent basis between researchers, scholars, and higher education administrators, Native student success will no longer be an exception to an unspoken rule, but instead, commonplace and general knowledge.

One major idea that stood out across all themes, and validated previous research (Angspatt, 2001; Guillory, 2008; Jackson, Smith, \& Hill, 2003; Waterman, 2012), was how critical encouragement and support of the family and community were for the participants. Waterman (2012) observed that family support and community connectedness were the most significant factors of success on educational journeys for Native American students. Just as the family and community benefit the student, one Lakota female can have a substantial impact on the community as a whole. Matrace (Personal communication, February 2017), recognized this when she discussed females not often recognizing what a positive impact they truly carry. She recalled how happy people in the community were for her. The domino effect that one Lakota female graduate has on a family and community is long-reaching. This is because Lakota females appear to not only be interested in building themselves up but rather on building up their tribal nations.

Brayboy (2006) discussed the importance of tribal nations to regain their sovereignty, autonomy, self-determination, and self-identification. TCUs were created, in part, for this purpose. They are providing a means to this TribalCrit tenet by aligning their educational policies and curriculum with the needs of the community and tribal nation. In addition, Brayboy's TribalCrit lens aim toward the life and educational situations of Native Americans and this is why we believe it is imperative to use Native American lens when conducting research in India Country.

\section{Conclusion}

For most of the participants, the people in their lives who were educated and had a high expectation for educational success in their lives were female. Whether it was a sister pursuing her degree first, a mother who always showed that education was paramount by getting an education herself, a grandmother recommending education as the best path, or a four-generation chain of educated females to follow in the footsteps of, there was always a story of female leadership and how it was inspirational and motivating to the graduates.

Although each participant brought their history, background, and experiences, they all shared three aspects in common. All participants were of Lakota ancestry. They were all female leaders within their families and communities. Lastly, every participant carried the Lakota virtue of wowacintanka (perseverance) because they were all successful graduates of a graduate studies program at Oglala Lakota College.

Even though these women persevered, and pushed through, there are some recommendations for ensuring continued support for Lakota females who are pursuing graduate degrees at TCUs.

(1) Utilize the high female influence to benefit recruitment and retention strategies. Recruit 
through family and kinship connections.

(2) Continue to offer grant programs and financial assistance, as this one factor is what convinced most of the participants that the program was attainable.

(3) Share the education histories and accomplishments widely.

(4) Evaluate the culture at TCUs to ensure that institutional conflict is not contributing to the student dropout rate.

(5) Establish a mentorship program for students to aid in course completion, navigation of processes, and career development.

The Lakota female perspective on what factors motivated them to obtain their graduate degree at a TCU successfully provides an alternative view on the educational and cultural richness that has not been previously visible. The women in this study are now part of the high female influence that was modeled for them. They now have the competency in navigating the formal and informal processes of higher education. The power that these women have within their homes, communities, and the larger world takes on new meaning after graduate degree completion. The Lakota female ambition, proven through this research, to give back and reciprocate knowledge is invaluable to future generations.

\section{References}

Al-Asfour, A., \& Abraham, M. (2016). Strategies for retention and persistence for Native American students in higher education. Tribal College and University Research Journal, 1(1), 46-56.

Al-Asfour, A., \& Bryant, C. (2011). Perceptions of Lakota Native American students taking online business course at Oglala Lakota College. American Journal of Business Education, 4(10), 43-50. https://doi.org/10.19030/ajbe.v4i10.6063

Angspatt, J. (2001). Barriers and contributions to American Indian academic success at the University of Montana: A qualitative study. Retrieved from http://scholarworks.umt.edu/cgi/ viewcontent.cgi? article $=10432 \&$ context $=$ etd

Brandt, C. B. (2008). Scientific discourse in the academy: A case of an American Indian undergraduate. Science Education, 92(5), 825-847. https://doi.org/10.1002/sce.20258

Brayboy, B. M. (2006). Toward a tribal critical race theory in education. The Urban Review, 37(5), 425-446. https://doi.org/10.1007/s11256-005-0018-y

Butler, K, R., \& Al-Asfour, A. (2018). Factors that influence the persistence of Native American students at tribal colleges and universities. Tribal College and University Research Journal, 3(1), 42-57.

Crazy Bull, C. (2014). Woksape: The identity of tribal colleges and universities. Retrieved from http://blogs.nwic.edu/teachinglearning/2011/05/25/woksape-the-identity-of-tribal-colleg es-discussion-paper 
Crazy Bull, C., Lindquist, C., \& Gipp, D. (2015). An act of sovereignty: Governing tribal higher education. Tribal College Journal, 26(4), 18-22.

Creswell, J. (2007). Qualitative inquiry \& research design: Choosing among five approaches (2nd ed.). Thousand Oaks, CA: Sage.

Devers, K. J., \& Frankel, R. M. (2000). Study design in qualitative research-2: Sampling and data collection strategies. Education for Health, 13(2), 263. https://doi.org/10.1080/1357628 0050074543

Gambrell, K. M. (2016). Lakota women leaders: Getting things done quietly. Leadership, 12(3), 293-307. https://doi.org/10.1177/1742715015608234

Gibson, S. (2015). Increasing the High School Graduation Rate of Native American Students in Public Schools. Retrieved from http://scholarship.claremont.edu/cgiviewcontent.cgi?article $=2039 \&$ context $=$ cmc_theses

Gill, P., Stewart, K., Treasure, E., \& Chadwick, B. (2008). Methods of data collection in qualitative research: Interviews and focus groups. British Dental Journal, 204(6), 291-295. https://doi.org/10.1038/bdj.2008.192

Guillory, J. P. (2008). Diverse pathways of "giving back" to tribal community: Perceptions of Native American College graduates (Doctoral dissertation, Washington State University, USA).

HeavyRunner, I., \& DeCelles, R. (2002). Family education model: Meeting the student retention challenge. Journal of American Indian Education, 41(2), 29-37.

Jackson, A. P., Smith, S. A., \& Hill, C. L. (2003). Academic persistence among Native American college students. Journal of College Student Development, 44(4), 548-565. https://doi.org/10.1353/csd.2003.0039

Kagan, C., \& Gray, J. (2011). The Northern Plains Biculturalism Inventory to Assess Cultural Affiliation. https://doi.org/10.1037/e705872011-001

Makomenaw, M. (2014). Goals, family, and community: What drives tribal college transfer student success. Journal of Student Affair Research and Practice, 51(4), 380-391. https://doi.org/10.1515/jsarp-2014-0039

Miles, M., \& Huberman, A. (1994). Qualitative data analysis. Retrieved from https://books.google.com/books?hl=en\&lr=\&id=U4lU_-wJ5QEC\&oi=fnd\&pg=PR12\&dq=da ta + analysis + process + phenomenology\&ots $=$ kETC4HOZ1P\&sig $=$ ntM5YCEuNPm5jxF7Hribt $5 \mathrm{eEQsc} \# \mathrm{v}=$ onepage $\& \mathrm{q}=$ data $\% 20$ analysis $\% 20$ process $\% 20$ phenomenology $\& \mathrm{f}=$ false

Mirriam, S. (2009). Qualitative research: A guide to design and implementation. San Francisco, CA: Jossey-Bass.

Mulhall, A. (2003). In the field: Notes on Qualitative research. Journal of Advanced Nursing, 4l(3), 306-313. https://doi.org/10.1046/j.1365-2648.2003.02514.x 
Nelson, C. A., \& Tachine, A. R. (2018). Native student financial aid as Native nation building: History, politics, and realities. In S. J. Waterman, S. C. Lowe, \& Shotton (Eds.), Beyond access: Indigenizing program for Native American student success (pp. 65-82). Sterling, VA:Stylus.

Patton, M. (1990). Qualitative evaluation and research methods. Beverly Hills, CA: Sage.

Pavvel, D. M., \& Inglebret, E. (2007). The American Indian and Alaska Native Student's guide to college success. Westport, CT: Greenwood Press.

Pease-Pretty On Top. (2003). Events leading to the passage of the Tribally Controlled Community College Assistance Act of 1978. Journal of American Indian Education, 42(1). Retrieved from https://jaie.asu.edu/sites/default/files/421_2003_2_pease_0.pdf

Reyes, N. A., \& Shotton, H. J. (2018). Bringing visibility to the needs and interests of Indigenous students: implications for research, policy, and practice. Retrieved from file://C:/Users/olc-user/AppData/Local/Temp/Bringing-Visibility-to-the-Needs-and-Interests -of-Indigenous-Students-FINAL-2-1.pdf

Shotton, H. J. (2008). Pathway to the PhD: Experiences of high achieving American Indian females. ProQuest Digital Dissertation Database.

Shotton, H. J. (2016). Beyond reservations: Exploring diverse backgrounds and tribal citizenship among Native college students. Commissioned by the Racial Heterogeneity Project: National Commission on Asian American \& Pacific Islander Research in Education. Los Angeles, CA: UCLA Institute for Immigration, Globalization, and Education.

Shotton, H. J., Lowe, S. C., \& Waterman, S. J. (2013). Beyond the asterisk: Understanding Native students in higher education. Sterling, VA: Stylus Publishing. https://doi.org/10.1177/ 107429561302300105

Stake, R. E. (2000). Case studies. In N. K. Denzin \& Y. S. Lincoln (Eds.), Handbook of qualitative research (2nd ed.). Thousand Oaks, CA: Sage.

The Institute for Higher Education. (2007). The oath of many journeys, the benefits of higher education for Native people and communities. Retrieved from file://C:/Users/olc-user/ AppData/Local/Temp/ED539707.pdf

Thornton, S. (2006). An analysis of Tribal college student's backgrounds, motivations, and attitudes: The relationship to classroom retention (MSc. thesis, Montana State University, USA). Retrieved from http://scholarworks.montana.edu/xmlui/bitstream/handle/1/2422/ ThorntonS0806.pdf? sequence $=1$

Trujillo, O. V., \& Alston, D. A. (2005). A report on the status of American Indians and Alaska Natives in education: Historical legacy to cultural empowerment. NEA, National Education Association.

Waterman, S. J. (2012). Home-going as a strategy for success among Haudenosaunee college and university students. Journal of Student Affairs Research and Practice, 49(2), 193-209. 
https://doi.org/10.1515/jsarp-2012-6378

White Shield, R. (2009). Identifying and understanding Indigenous cultural and spiritual strengths in higher education experiences of Indigenous women. Wicazo Sa Review, 24(1), 47-63. https://doi.org/10.1353/wic.0.0022

Writer, J. H. (2008). Unmasking, exposing, and confronting: Critical race theory, tribal critical race theory and multicultural education. International Journal of Multicultural Education, 10(2). https://doi.org/10.18251/ijme.v10i2.137

Yin, R. (2014). Case study research: Design and methods. Thousand Oaks, CA: Sage. https://doi.org/10.4135/9781473915480.n38

\section{Copyright Disclaimer}

Copyright for this article is retained by the author(s), with first publication rights granted to the journal.

This is an open-access article distributed under the terms and conditions of the Creative Commons Attribution license (http://creativecommons.org/licenses/by/3.0/). 